\title{
In Search of Robert Lovell: Poet and Pantisocrat
}

\section{Introduction}

'At the close of the year 1794, a clever young man, of the Society of Friends, of the name of Robert Lovell, who had married a Miss Fricker, informed me that a few friends of his from Oxford and Cambridge, with himself, were about to sail to America, and, on the banks of the Susquehannah, to form a Social Colony, in which there was to be a community of property, and where all that was selfish was to be proscribed. ${ }^{1}$ Thus wrote Bristol publisher Joseph Cottle in his Reminiscences published in 1847. As any serious student of Romanticism knows, the most important of those 'few friends' mentioned by Cottle were Robert Southey and Samuel Taylor Coleridge, who were then gathering support for a small-scale transatlantic emigration scheme founded on radical egalitarian or so-called 'Pantisocratic' principles. It is chiefly in connection with this utopian venture that the 'clever young man' described by Cottle has, until now, typically featured in Romantic criticism, very much in a supporting if not peripheral role. But how much do we know about Robert Lovell? What kind of person was he? Why did Southey, and subsequently Coleridge, embrace him enthusiastically on first acquaintance and later downgrade their estimate of his qualities? What was Lovell's achievement as a poet, and what was his place in the early history of Romanticism in the South West? In this essay I attempt to answer these questions by reexamining established 'facts', gathering fresh evidence, and treating Lovell and his poetry as valid subjects in their own right rather than as a footnote to the budding careers of Coleridge and Southey. In that spirit, I shall begin by telling Lovell's story as far as possible from his own point of view, and introduce alternative or wider perspectives only once this portrait is firmly in place. 


\section{I. Life}

Robert Lovell was born on 25 October 1771 at Thomas Street, Bristol. ${ }^{2}$ He was the second son of a wealthy Somerset-born Quaker businessman, also called Robert, who initially set up as a cabinet-maker but became a pin manufacturer sometime in the late 1770 s. The elder Robert Lovell had ten children by his first wife, Edith (née Bourne), herself a devout Quaker who died in December 1781 in a shipwreck when returning from a religious visit to Ireland. ${ }^{3}$ Lovell had a further five children by his second wife, Lydia (née Hill), of Frenchay (near Bristol). Several of his children, including the younger Robert's elder brother, Bourne, died in childhood; they were produced roughly at the rate of one a year between 1769 and 1796, but there were no more children after Robert's early death in May 1796 at the age of $24 .^{4}$ Despite claims to the contrary in otherwise authoritative modern biographies of Coleridge and Southey, Lovell was not an Oxford contemporary of Southey's and in fact never attended university at all. ${ }^{5}$ He met Southey for the first time in late 1793 through their mutual friends, the Fricker sisters, a family fallen on hard times since the bankruptcy and premature death of their father, who had failed at successive business ventures. ${ }^{6}$ On 20 January 1794 Lovell married Mary Fricker, whom Southey's aunt had helped secure a place in the Bath-Bristol repertory company. The marriage is not recorded in the Society of Friends' Register of Marriages: since Mary was not a Friend it probably took place in St Mary Redcliffe, close to where the Frickers were living on Redcliffe Hill. There is little doubt that Lovell's family would have disapproved of the marriage, if only because Mary was a nonQuaker, but I have found no evidence to support the claim - recycled in numerous sources ${ }^{7}$ - that Lovell senior disowned or disinherited his son as a result of the union. Lovell may well have been formally disowned by the Society of Friends, since marriage in a parish church 
meant recognising the authority of a priest, but it does not follow that his family cut off all ties with him. One piece of counter-evidence is a lease of property owned by the Corporation of Bristol in the Old Market area to Robert Lovell senior. The original lease, dated 26 July 1788, gives his son Robert an interest in the property. Only in the month after Lovell's death, on 29 June 1796, did his father have the lease rewritten, adding his brother James, aged just three, as an interested party. ${ }^{8}$ Presumably, if Lovell senior had wanted to have nothing more to do with his son he could have ordered his affairs differently. As we shall see, Lovell remained in contact with his father up until his death.

Lovell's friendship with Southey developed rapidly and they soon began planning collaborative poetic ventures. A joint volume using the pen-names "Bion" and "Moschus" was issued in December 1794 by a Bath publisher, Richard Cruttwell, although this was preceded by Lovell's own self-published Bristol: A Satire. In August 1794 Lovell made the acquaintance of Coleridge when the latter arrived in Bristol at the end of his walking tour in Wales, full of enthusiasm for the Pantisocratic project he had hatched with Southey in Oxford the month before. ${ }^{9}$ Recalling this encounter - which marked her own introduction to her future husband - many years later, Sara Coleridge said that she 'first saw him at $\mathrm{R}$ [obert] L[ovell]'s' and that he was 'brown as a berry'; Lovell, described by Sara as 'gay \& smart', declared that 'he can have prog here - but he must sleep elsewhere' ${ }^{10}$ Lovell soon overcame his initial aversion to Coleridge's appearance and his scepticism towards the transatlantic project and became a convert to Pantisocracy; later that year he tried unsuccessfully to enlist Cottle as a partner in the scheme and took the opportunity to read some of Southey's and Coleridge's manuscript poems to him. ${ }^{11}$ With Cottle's interest aroused, he soon introduced first Southey, and then Coleridge, to the man who would play such an important part in their literary careers. 
In 1795 Lovell drops out of the picture as Southey's and Coleridge's relationship grew closer yet more fractious in their shared lodgings at 25 College Street. It was from here that they undertook their public lecturing, went on walking expeditions, and endlessly discussed and ultimately backtracked on their American dream; when they married Edith and Sarah Fricker towards the end of the year they had fallen out so comprehensively that neither attended the other's wedding. Of what Lovell was doing during this period little is known: he is mentioned only twice in Southey's surviving letters from 1795 and disappears from view in Coleridge's correspondence between January and November. However, he definitely attended the first of Coleridge's political lectures at the Corn Market in late January or early February, if the later testimony of the anonymous ' $Q$ ', responding to the publication of Coleridge's Biographia Literararia (1819), is to be believed. This correspondent, who claims to have known Coleridge well in the mid-1790s, takes exception to the latter's denial of having been a democrat in his youth and cites his personal memory of the Moral and Political Lecture, 'at which Southey and Lovell were also present', in refutation. ${ }^{12}$ Lovell was also apparently present at a meeting held at Bristol Guildhall on 17 November to congratulate George III on surviving a recent assassination attempt. The assembly was hijacked by a group of citizens who wished to petition the king for 'a speedy Termination of the present War', and (as reported by the local Star) 'Mr Lovel' was one protester who made 'several fruitless attempts [...] to deliver their sentiments on this extraordinary occasion' ${ }^{13}$

In between these public appearances, Lovell seems to have tried to sabotage Coleridge's marriage. Cottle recalls that Coleridge began denouncing Lovell as a 'villain', complaining that the man who once promoted his 'connexion with Miss Fricker' now opposed their union. ${ }^{14}$ According to Molly Lefebure, Lovell's expressions of doubt about the 
marriage had much to do with his perception that Coleridge's 'indolence' had its root cause in his incipient opium addiction, but this is at best a highly speculative conclusion. ${ }^{15}$ Nevertheless, his feelings towards Coleridge had cooled since the early rush of Pantisocratic enthusiasm in the second half of 1794 and there is no doubt that, as M. Ray Abrams puts it, 'in the gradual estrangement that grew up between Southey and Coleridge [...] Lovell was drawn more toward the common-sense point of view with Southey'. ${ }^{16}$

The truly life-changing event of 1795 for Lovell was the birth of his son, Robert, on 23 September. His occupation at that time was given in the Register of Burials as 'accomptant' (in modern terms, an accountant). Unfortunately, he did not get to enjoy fatherhood for very long. In April 1796 he fell ill on a trip to Southampton and died on 3 May shortly after his return to Bristol. At the time of his death he was described as a pin manufacturer, like his father. This fact alone puts in question the filial rebelliousness or disloyalty of which Lovell is sometimes accused; it may even suggest that he was working for his father at the time of his death. He was buried at Quakers Friars and, according to Cottle, the now divided and disillusioned Pantisocrats shed tears into his grave. ${ }^{17}$ In the months and early years that followed his son was brought up by Quaker relations in Bristol but his widow was taken in by the Southeys and eventually went to live with them at Greta Hall in Keswick. As Robert Lovell Junior grew older, Southey faced continual difficulty in getting the Lovell family to take financial responsibility for his education. Having failed to get the boy into Christ's Hospital, he was glad finally in 1809 to see him apprenticed to a London printer and bookseller, William Pople. Southey was initially optimistic about his prospects, but the lack of a stable upbringing and the separation from his mother seems to have affected the boy badly, and Sara Coleridge would later observe that he belonged to 'the class of dry crustaceous animals' with a crust 'formed partly by external pressure, and only in part by 
the hard materials secreted from within'. Robert Lovell Junior, she went on, had had 'to shift and scramble a good deal for himself, to bear up against a hard world which would have crushed or injured the frame it did not render to a certain degree tough \& unyielding ${ }^{19}{ }^{19}$ Lovell Junior predeceased his mother, failing to return from a holiday in Italy in 1839, 'presumed murdered by brigands' ${ }^{20}$ The following year Mary had given up hope: ‘ never expect to hear of him more', she confessed to her sister. ${ }^{21}$

\section{Personality}

These are the bare bones of Robert Lovell's tragically abbreviated existence: it was a short life, about which we are lamentably short of hard information. But is it possible to build on these sparse facts and make a rough sketch of Lovell's personality? That he was the son of a rich Quaker businessman and therefore part of a politically significant religious grouping which made up approximately six per cent of the population of Bristol does not tell us as much as one might expect. ${ }^{22}$ Robert Lovell seems to have disowned the religion of his parents: Coleridge claimed that he was an atheist when he first made his acquaintance. ${ }^{23}$ Sarah Fricker's description of Lovell as of 'gay and smart' appearance obviously conflicts with Quaker traditions of plain dress. Presumably it is on some such superficial basis that Southey warns a friend in December 1793 that he might consider Lovell 'eccentric' when taking receipt of a hand-delivered letter. ${ }^{25}$ This is the conclusion Rayne Nickalls comes to: 'Does eccentricity mean that like Shelley and Byron he wore no neck cloth, but a soft shirt open at the neck? Probably. Probably he had longish hair; perhaps no hat. ${ }^{26}$ Sartorially, Lovell in all likelihood stood out; whatever his principles and beliefs, his appearance was a declaration of independence from his parents, family, and faith community. 
Soon after meeting Lovell for the first time Southey described him as 'very moderate in democracy', but it is clear that the two of them quickly established common ground in this area. Just four months later, in the only complete letter of his to Lovell that has survived, Southey transcribes for him a poem he has just written ('The Exiled Patriots') on two Scottish reformers recently tried for sedition and sentenced to transportation; the clear presumption is that Lovell will appreciate what he describes as a 'delectable dose of democracy' and share his dismay at the fate of the 'virtuous exiles'. ${ }^{27}$ In September 1794, with Lovell enlisted as a Pantisocrat, Coleridge sends his new acquaintance 'fraternal Love' in plain allusion to the French Revolutionary slogan. ${ }^{28}$

Politics aside, the picture one forms of Lovell from miscellaneous sources is not entirely of a piece. Cottle's memory is of a clever, well-read, enthusiastic and optimistic young man with an 'open frankness' that Cottle thought characteristic of his Quaker roots. ${ }^{30}$ Southey's first impressions were of a good conversationalist and a man of 'very great abilities' - a judgement that he would upgrade a few months later to a 'Man of mighty mind'. One rather opaque reference to Lovell's principles having 'rescued him from libertinism' suggests that there may have been a few skeletons in his new friend's cupboard. ${ }^{31}$ Lovell was evidently reliable and well organised: his father seems to have trusted him to mind his business during periods of absence while he was still in his teens, while the business-like Southey was happy to use him as an intermediary with publishers and entrusted him with various commissions on trips to London. It was Lovell, for instance, who was asked to tout some of Southey's poems around London publishers in October 1794; while he was there, he solicited the views of the imprisoned Thomas Holcroft on both Pantisocracy and a proposed trial scheme in Wales. ${ }^{32}$ In terms of leisure activities, Lovell was said to dislike shooting, but the anonymous author of a pamphlet satirising various young 
Bristolians in Cottle's circle claimed that his fondness for pugilism and racquet sports was in danger of perverting his talents to 'indifferent purposes'. ${ }^{33}$ Perhaps the reference to pugilism helps explain why Lovell was also said to have been thrown out of the theatre in Bristol on one occasion, for unstated reasons. ${ }^{34}$

One way of obtaining insight into an individual's personality is to study their reading habits, and to this end we are fortunate, in Lovell's case, to have available the borrowing registers of the Bristol Library Society. Southey's and Coleridge's borrowings from the Bristol Library have long been known to scholars, thanks in large part to the work of Paul Kaufman and George Whalley, ${ }^{35}$ but Lovell's have not previously been brought to light. He first enters the register on 7 September 1790, when he took out the first volume of Patrick Brydone's $A$ Tour through Sicily and Malta (1775), and features for the last time on 25 April 1796, when he borrowed the first volume of Joseph Townsend's Journey through Spain in the Years 1786 and 1787 (1791). A subsequent annotation in the register alluding to a 'Letter May 27' perhaps records formal notification of Lovell's untimely death earlier in the month.

Lovell's numerous borrowings during the first two years of his Library membership over 130 visits up to November 1792 - show an eclectic range of interests. The taste for travel literature evidenced by his first and last visits is reflected throughout his borrowing record, with works such as Giuseppe Baretti's Account of the Manners and Customs of Italy (1768), Hester Piozzi's Journey through France, Italy, and Germany (1789), and John MacDonald's Travels in Various Parts of Europe, Asia, and Africa (1790) among the works he took out in the first two years. Science and medicine were conspicuous interests, with works such as Richard Watson's four volumes of Chemical Essays (1781-7), Thomas Arnold's Observations on the Nature, Kinds, Causes, and Prevention of Insanity (1782-6), and Joseph Priestley's Experiments and Observations on Different Kinds of Air (1774-86) providing him 
with some weighty reading matter. Lovell also accessed a great deal of mainstream (chiefly British) literature, literary criticism, and literary biography and immersed himself in the periodical press, taking out complete volumes of the Analytical Review, Monthly Review, and Samuel Johnson's Rambler one after the other.

Lovell's visits to the Bristol Library became less frequent in 1792 , while in 1793 , for unknown reasons (perhaps the progress of his relationship with Mary Fricker was a factor?), he went only twice. In 1794 his borrowings pick up again, and from this point onwards, as his friendships with his radical Pantisocratic comrades evolve, there is arguably a sharper political edge to his reading preferences: he works his way through the first edition of William Godwin's Political Justice, reads Helen Maria Williams's Letters Written in France in the Summer 1790 (1790), , digests Erasmus Darwin's controversial scientific poem, The Botanic Garden (1792), and, shortly before his death, gets to grips with Mary Wollstonecraft's Rights of Woman (1792). Although he also continued to borrow more conservative literary works, it is hard not to conclude that his intimacy, however brief and fragile, with Southey and Coleridge in their revolutionary youth had an impact on his reading, tilting his choices towards some of the most challenging and progressive works of the 1790s.

While Lovell's documented reading habits offer intriguing clues to the growth of his mind, his own voice can be heard in just a handful of surviving letters. A letter to his parents in May 1788 conveys a strong sense of filial love and duty: he assures his father that he is following all his instructions regarding the business and that they 'go on very comfortably', and to his mother expresses a polite reluctance to hasten her return to Bristol: 'I would not wish to be in any Degree the Means of either detaining or hurrying you, tho' I should be exceedingly glad to see you again'. ${ }^{36}$ (Of course, the sixteen-year-old Lovell would not be the 
first teenager to be in no hurry for his parents to return home from a trip away.) More moving is the last long letter a sick Robert Lovell wrote to his wife from Winchester on what turned out to be his last journey away from Bristol. He does his best to reassure Mary as to the severity of his illness, referring to 'that fainting and Giddiness which often oppresses me in very hot weather, accompanied by a most violent Head-ach, \& pain in many Parts of my Body'. However, the very insistence with which he dwells on his symptoms, even as he states that there is nothing to worry about and that his wife should not expect to 'see me come home dreadfully ill \& unable to stand', may well have had the reverse effect on his addressee. Lovell mentions that he has written to his father and 'shall get an answer from him tomorrow at South[amp]ton': it is clear that the 'Business' of his journey involves his father and there is little sign here of that deep estrangement from his family that previous commentators have inferred. He concludes with thoughts of his son: 'A Thousand Kisses to the dear little Boy - while he is well I cannot be unhappy for my own indisposition. I do not cease a Moment to think of him. ${ }^{\prime 37}$ Lovell's very last letter, sent from Southampton five days later, merely notes flatly that he is not getting better and has taken a place on the Bristol coach for Monday morning: 'adieu, am very weak. Hope you are all well. ${ }^{38}$ Ten days later he was dead, Coleridge having sat up all night with Mary as Lovell's 'deep, unintermitted groans [...] drove [his] poor young Sister-in-law frantic' ${ }^{39}$

So: a lapsed Quaker possessed of moral principles and fired up with democratic politics in the early years of the French Revolution; a man of mighty mind whose intellectual abilities outran his formal education and whose reading ran the gamut from Cavallo's Treatise on Electricity to Warton's Essay on the Genius and Writings of Pope; a man described as ardent and optimistic, but also gentle and unassuming; a loving and dutiful son who nevertheless married an actress against his father's wishes and risked the financial 
consequences; a man keen on physical exercise who nevertheless seems somewhat hypochondriacally self-absorbed; a man who reviled blood sports yet was not averse to a gentlemanly punch-up and was no stranger to scenes of social disorder. Maybe this all goes to show how difficult it is to construct a character portrait from scarce and fragmentary documentary records; maybe, on the other hand, Robert Lovell was a more complex individual than the background figure whom it has been so easy to ignore in Romantic biography and criticism to date.

\section{Literary Friendships and Coterie Life}

Moving from questions of personality to more narrowly literary concerns, what is Lovell's place in the early history of Romanticism - in Bristol, the South West, or beyond? Posterity has made no cataclysmic blunder in this respect: there is no doubt that Lovell's role can only ever be regarded as a brief cameo; nevertheless, it deserves more attention than it has received to date, so I shall first consider his contribution to the Cottle circle before turning in conclusion to look more closely at his own poetic legacy.

In May 1806 Southey named Lovell as one of three men, now dead, who had had 'no little effect upon my character \& after life' ${ }^{40}$ This is perhaps a surprising thing to say about a man whom he had known for just over two years - even more surprising when he had stated soon after Lovell's death that the latter had 'sunk much in [his] esteem'41 (for reasons that sadly remain impenetrable). It is, however, consistent with his determination declared in the same month in which he made that negative remark - to produce a posthumous edition of Lovell's poems as a 'monument to his memory'. ${ }^{42}$ That edition never materialised, but a decade later Southey was keen to include Lovell in his three-volume anthology, Specimens of the Later English Poets (1807), only for his wishes to be 
mysteriously disregarded by his co-editor, Grosvenor Bedford. He had drafted a prefatory notice remembering his friend as 'a man so naturally urbane, so close \& clear in reasoning, \& yet in argument so gentle \& unassuming', whose death was 'the most sudden check I ever experienced' ${ }^{43}$

There is ample evidence that Lovell made a significant impact on both Southey's and Coleridge's lives. His poetry made a huge impression on Southey at the start of their friendship, with Southey going so far as to say that he knew 'no Author in our language that surpasses him'. ${ }^{44}$ Southey ranked Lovell's poetry above his own, and was 'pleased at finding a superior' who encouraged his own literary endeavours and provided a sounding board for new verse. ${ }^{45}$ The relationship kick-started his publishing career: Lovell became his first collaborator and went with him to persuade the Bath publisher, Richard Cruttwell, to bring out their Poems of $1795 .{ }^{46}$ They wrote companion poems for that collection (Lovell's 'The Decayed Farmhouse' clearly complements Southey's 'The Miser's Mansion') and were planning another joint volume - which never appeared - in the first year of their acquaintance. Cruttwell also agreed to publish Southey's epic, Joan of Arc, and Lovell helped with 'several revisions' to the poem in the summer of $1794 .{ }^{47}$ There is strong evidence that for a short while they formed a genuine creative partnership: in the only complete letter of Southey's to Lovell that has survived, he shares five poems with his new friend, including the poem on the two Scottish political exiles mentioned above, conveys his thoughts on Priestley's emigration to America, and provides an update on his composition of the first version of Madoc. ${ }^{48} \mathrm{It}$ is plain that Lovell is someone with whom he feels that he can freely discuss anything, including political matters on which they appear to be very much on the same page. The lighter side of this intimacy is shown in another letter of Southey's from June 1794, which includes rival odes by Lovell and himself to an Oxford student ('Griggin') 
characterised as 'the ne plus ultra of folly'. However lamentable the creative products may be (Lovell: 'Such sad such hopeless case as thine / I would not keep a pig in - / Then die as tis thy duty to / And rid the world of Griggin!'), it is fascinating to find the Quaker-born Lovell co-opted into the boisterous world of undergraduate humour; moreover, the competitive poem-making evidenced by this letter is a recognised feature of 'coterie literary production', an aspect of creativity predicated on social interaction rather than the solitary visitations of a Muse. ${ }^{49}$ It may well be that Lovell thrived in such an environment.

When Coleridge appeared on the scene and the Pantisocratic project took centre stage, Lovell not only signed up himself, his wife, and several family members as emigrants, but also proselytised on behalf of the scheme to such an extent that Southey's aunt, who threw her nephew out of the house when she first heard of his plans, blamed and abused him for it 'most unmercifully'. ${ }^{50}$ Initially sceptical about Pantisocracy, he became its main recruiting sergeant; as mentioned above, he even visited the jailed Jacobin novelist, Thomas Holcroft, in Newgate prison to spread the word about the transatlantic project. Lovell introduced first Southey, then Coleridge, to local publisher Joseph Cottle, smoothing the way for these crucial early connections with the literary marketplace by reading Cottle some of their manuscript poems. He was an adept and energetic facilitator, whose interventions were hugely consequential: Cottle, in fact, quickly supplanted Cruttwell as publisher of Joan, and Southey's professional relationship with him would continue with the collections of 1797 and 1799; Coleridge, for his part, would depend on Cottle for his Poems of 1796 and 1797 and, ultimately, for the ground-breaking Lyrical Ballads of 1798.

Despite his fraternal embrace of Lovell in the early days of their acquaintance, Coleridge was never as wholehearted an admirer as Southey. Rayne Nickalls suggests that this reticence had its roots in a longstanding dislike of Quakers (as distinct from their 
religion), although this is hard to reconcile with his close friendship with Quakers such as Thomas Wilkinson, whom Dorothy Wordsworth was to call 'the Father of The Friend' ${ }^{51}$ It also takes little account of how far Lovell had strayed from the religion of his parents: certainly his mother, who 'was deeply concerned to bring up her Children in plainness and moderation', according to her local Quaker community, ${ }^{52}$ would have disapproved of many aspects of the character I have sketched above. Whatever the reasons may have been, by the end of 1794 Coleridge had decided that Lovell's poems showed 'no taste-or simplicity of feeling' and that Lovell did not understand his and Southey's political creed. ${ }^{53}$ (The letters in which these forthright views were expressed also contained a good deal of what might generously be termed 'constructive criticism', and indeed rewriting, of Southey's own poetry.) The dynamics of the literary relationships in the Southey circle were clearly shifting at this time. Already, Lovell's contribution to a tripartite project, The Fall of Robespierre the highly topical verse drama written in a matter of days when news of the Thermidorian coup reached England in late August - had been axed because it was 'not in keeping' with the other two parts, with Southey stepping in to plug the gap. ${ }^{54}$ Then Coleridge took over as Southey's main collaborator in a further major revision of Joan in the first half of 1795 , in the run-up to its publication by Cottle. ${ }^{55}$ It would seem that, although Lovell's Bristol connections were still valued and his campaigning on behalf of Pantisocracy was indispensable, the appearance on the scene of the more charismatic and hugely more talented Coleridge led to his rapid dethronement as Southey's principal literary confidant. In this period, as David Fairer has observed, 'friendships among the Coleridge circle were being bonded by poetry', but poetry could also be a meeting-ground on which friendships were challenged, strained, or subverted. If, as Fairer suggests, Coleridge was 'conscious of friendship as something that needs to be negotiated with care', ${ }^{56}$ that care did not 
necessarily extend far beyond those few individuals on whom, at any given time, he chose to concentrate his affections.

If Lovell was aware of Coleridge's low opinion of his poetry and political nous, he responded in kind, as noted earlier, by doing his best to defer or derail Coleridge's marriage to Sarah Fricker. When Coleridge's and Southey's relationship imploded towards the end of 1795, Lovell sided with the latter and helped drive a thicker wedge between the two poets. Coleridge thereby lost the friend he regarded as his 'Sheet Anchor', ${ }^{57}$ but his emotional needs were arguably such that he could not for very long do without a psychologically more stable confidant and someone he could look up to in terms of poetic ambition, and this paved the way for his relationship with his new 'best friend', William Wordsworth, and ultimately for Lyrical Ballads.

To refer to Lovell as primarily an intermediary, as the witting or unwitting practitioner of a form of literary midwifery, would seem to risk slipping into the condescension of posterity. But this is to ignore the growing body of work that stresses the importance of groups and group identities in literary history. Recent studies in Romanticism have given welcome new attention to the coterie as an essential middle ground between the opposing critical poles of the individual writer on the one hand and the generalising categories of race, class, and gender on the other. Far more than has been traditionally recognised - owing in part to the powerful legacy of Romanticism's rhetoric of solitary genius - writers prosper within a circle of like-minded individuals. Along with the sociability and group activities that provide a valuable sense of belonging, such coteries tend to perpetuate certain practices associated with an earlier manuscript culture, notably the production of writing of a collaborative or dialogic nature and, indeed, the continued circulation of manuscript volumes alongside print publication as part of a complex web of 
private and public dissemination. In the Romantic period, groups organised around the publisher Joseph Johnson, the Liverpudlian historian and social reformer, William Roscoe, and the Irish novelist, Marguerite Blessington, have been attracting attention alongside better-known social entities such as the Bluestockings, the Lake School, and the Cockney School. Jeffrey Cox has proposed the term 'communal romanticism' for this new way of viewing Romantic literature 'not as the achieved vision of isolated geniuses but as the continually contested project of opposing groups of writers'.$^{58}$ As Richard Cronin, Paul Cheshire and Nicholas Roe (among others) have recently highlighted, the circle of young writers centred on Joseph Cottle's High Street bookshop was a key part of this contested cultural field in the 1790s, providing a fostering community for aspiring poets united by their opposition to the slave trade and the war with Revolutionary France, their concern for civil liberties, and 'a defiant provincialism through which they expressed their distrust of the centralised state' ${ }^{59}$ The Cottle circle manifested all the characteristics of coterie literary production as I have summarised them; Southey's Annual Anthology (1799-1800), which introduced many Bristol-based poets to a national audience, was perhaps its most lasting memorial. Lovell was an active and influential member of that circle (which also included writers such as Thomas Beddoes, Humphry Davy, and Cottle's brother, Amos), and it is in that context that we can make a fairer and more appropriate assessment of his literary significance.

\section{Poetic Legacy}

There is no doubt that the poems published both in his lifetime and posthumously are an incomplete representation of Lovell's output. Texts of only fifteen poems, eight of them sonnets, survive. Southey refers to poems on the snowdrop and the nightingale, of which 
there is no trace; he also writes of Lovell's particular skill with verse epistles, a designation that cannot safely be applied to any of his extant poems. ${ }^{60}$ We have to assume that the poems gathered in anthologies such as Park's Works of the British Poets (1808) and Davenport's The British Poets (1822) were his best, although, if that is so, to the modern eye it is hard to justify Southey's extravagant praise of his talent. His poems embody a set of attitudes and themes which might be taken as fairly representative of Cottle's school of poets and the communal project of South West Romanticism: sympathy towards poverty and inequality, anti-Catholicism, anger against oppression, a preference for an active life mindful of social duty, a distaste for luxury and self-indulgence, and an anti-metropolitan bias towards scenes of rural domesticity. Among specific poems, Southey shrewdly selected Lovell's sonnet on Stonehenge (which had already appeared in Coleridge's periodical, The Watchman) for inclusion in the first volume of The Annual Anthology. This sonnet, in which a Druid-like form is heard complaining about 'holy rites unpaid' (11) and crowds of visitors profaning a sacred site before his voice is lost in the passing storm, has a nice sense of atmosphere, albeit one that is shaped in large part by stock eighteenth-century narratives of the progress of poetry. ${ }^{61}$ 'The Wish', a poem addressed to Southey at a time when they were contemplating a joint volume under the pseudonyms 'Valentine' and 'Orson', 62 shows Lovell combining public and private themes: his 'wishes' range from the abolition of slavery and restraints on 'despotic' power (21) to the reciprocal love of a woman to the discovery of some 'congenial mind' (35) for intellectual companionship. His final stanza - 'indulgent heav'n vouchsafed the boon to send, / A youth I found, and just and mild was he' (39-40) suggests that Southey is the worthy object of his spiritual longings. Perhaps Lovell's best short poem is another, untitled sonnet ('The cloudy blackness gathers o'er the sky') 
published in the Annual Anthology, which describes a gathering political storm in which conflicting passions of indignation, fear, and hate may bring the country to its knees:

$$
\text { Indignation high }
$$

Might hurl promiscuous vengeance with wild hand

And Fear, with fierce precipitation throw

Blind ruin wide; while Hate with scowling brow

Feigns patriot rage. $(4-8)^{63}$

With reference to the experimental work on electricity carried out by Joseph Priestley and Benjamin Franklin, the speaker goes on to appeal for men of similar stature to channel the revolutionary energy and help build a fairer society out of the current turmoil - to 'shape the lightning's course / To purify Creation, not destroy' (11-12).

However, it is probably his Bristol: A Satire that earns Lovell a place in the extended Romantic canon. This poem was a brisk response to another poem on Bristol, Romaine Thorn's Bristolia (1794). Thorn's eulogy of the city praises its commercial prowess and its citizens motivated by honour, justice, and a healthy thirst for trade. Among the snapshots that the poem offers are happy dockyard workers unloading ships and jolly sailors preparing their ships for departure; Bristol ladies promenading on College Green are said to outshine in beauty the classical goddesses Venus and Diana and - perhaps appropriately in a major port - Helen of Troy:

Beneath the branches of th'extended trees,

They take their circuit, and imbibe the breeze.

Not HELEN'S face, which prov'd the fall of TROY,

Outshone the charms BRISTOLIA'S FAIR enjoy. ${ }^{64}$ (53-6) 
Thorn celebrates Bristol's numerous charities (singling out slave trader and philanthropist Edward Colston - a controversial figure in modern Bristol - for particular praise) and the waters of Hotwells spa (which can apparently cure tuberculosis). He concludes his poem by taking the view from Brandon Hill and seeing with satisfaction how civil strife of the past has been replaced by peace and prosperity:

Buildings superb, and lofty spires, surprise

The gazer's senses, and enchant his eyes;

Whilst to his eyes, in quick vibration, come

The noise of trucks, and city's ceaseless hum:

The shouts of sailors, as their castles ride,

With waving streamers, on the crystal tide;

All which declare, to Bristol's busy throng

That commerce, wealth, and industry belong. (141-8)

The full historical and political context of Thorn's celebratory address is made plain in the final verse paragraph. It is, of course, only civil strife that is now a thing of the past: with Britain now at war with Revolutionary France, Thorn is keen to recognise the 'fearless youth' (155) of Bristol who have formed a local militia and are ready to defend 'their COUNTRY, and its laws' (152) against the anarchic, bloodthirsty mob on the other side of the Channel.

Lovell's poem ${ }^{65}$ incorporates plenty of ironic allusions to Thorn's panegyric to offer a very different vision of his native city - a city disfigured by smoke and dust and seemingly sinking into the mud of the Avon. Lovell's Bristol is ruled by the goddess, Dullness, and the god, Avarice (alternatively personified as Plutus, the ancient Greek god of wealth). Together they inspire a lust for money and the perversion of truth by purely financial considerations: 
Full oft the God inspires the golden dream

Of cent per cent, and many a goodly scheme:

In all his Sons the mystic signs we trace,

Pounds, Shillings, Pence appear in every face.

Here worth is prized, if worth will aught obtain,

And truth is judg'd by rules of loss and gain. (95-100)

The ruling deities encourage bad poets such as Thorn to produce their drivel while neglecting the rare genuine geniuses such as Chatterton, who saw Bristol reward vice and folly while awarding his own achievements no more than 'posthumous applause' (153). Lovell is at his best not when snidely rebuking his fellow poet but when addressing his main theme directly:

Trade, mighty trade, here holds resistless sway,

And drives the nobler cares of mind away.

To this sole object every effort tends,

And virtue dies and pliant honor bends;

No soft humanities are cherish'd here,

No sympathetic feeling prompts the tear. (200-5)

In the relentless, generalising condemnation of an entire populace epitomised by these lines Lovell's poem resonates most clearly with an earlier satire on his home city, Richard Savage's 'London and Bristol Delineated', which speaks of Bristolians preferring the 'ruthless Sneer' to 'melting Pity' and denounces the city as a 'Blank of Sciences' and 'Dearth of Arts'. ${ }^{66}$ Lovell's satire is, however, more topical than Savage's, with a level of referential detail that would come naturally only to a writer who had lived in Bristol all his life. He moves on to criticise Bristolians' lack of charitable activity (citing delays in completing the new Infirmary 
owing to a lack of donations, and the failure to support a winter concert ${ }^{67}$ ), condemn the city's prominence in the slave trade ('Slaves torn and mangled, cultivate the sweet, / That trade may thrive, and luxury may eat' [282-3]), and offer examples of Bristol's readiness to sacrifice rights and liberties on the altar of its presiding deity, Avarice. The poem ends with sardonic reflections on the Bristol Bridge riots of 1793 - triggered by the unexpected decision to renew tolls following the expiration of a lease - which left eleven dead and fortyfive injured, and the abandonment of plans to build a new prison solely on grounds of expense rather than any regard for liberty. The 'charter'd powers' of Bristol Corporation, Lovell concludes, amount to "'The right" and privilege "of doing wrong"' (308-9).

If this was Lovell's view of his home city, he was presumably all the more grateful for the liberal and artistically inclined community that the Cottle circle provided, and his enthusiastic immersion in the lives and plans of his new, radical-minded, Pantisocratic friends is readily explained. As I have suggested, those relationships seem to have been cooling off even before Lovell's premature death, and on a personal level the latter arguably had every right to feel used and abused: he was, in effect, collateral damage in the intense and unstable relationship between Southey and Coleridge. But Lovell deserves more respect than to be seen merely as part of the emotional detritus of two greater names. The Cottle circle made a significant contribution to the early history of Romanticism and the very presence of the circle was a vital factor in the contribution that its leading members made. At a time when local and regional Romantic networks are deservedly receiving more attention it is right to acknowledge Robert Lovell's part in that communal endeavour. 'Why always Dorothea?' is the narrator's famous interjection in chapter 29 of Middlemarch, as George Eliot forces her readers to adopt a different point of view and accept that the disagreeable Casaubon possesses an 'equivalent centre of self' worthy of their interest and 
sympathy. ${ }^{68}$ To some extent the purpose of this essay might be phrased in similar terms: why always Coleridge? Or at best Coleridge and Southey? We are so habituated to hearing of Lovell merely as a footnote to the emergence of two canonical literary figures that, without demur, an individual life is reduced to a handful of clichés, and errors and misunderstandings of the kind that I have identified are lazily perpetuated by scholars who should really know better. Instead, I have tried to explore what happens when one performs the Eliotian swerve and switches background and foreground, puts a 'minor' or obscure figure such as Lovell into the critical spotlight. We may never feel that we have resurrected the 'Man of mighty mind' who so impressed Southey on first acquaintance, but I hope to have shown that we discover an intriguing individual whose shadowy existence in lateeighteenth-century literary history is an oversight worth correcting. 
Notes

\footnotetext{
${ }^{1}$ Joseph Cottle, Reminiscences of Samuel Taylor Coleridge and Robert Southey (London: Houlston and Stoneman, 1847), p.2.

${ }^{2}$ So called in the Society of Friends' Register of Births. More correctly this is St Thomas Street, in the Redcliffe area of Bristol, which still exists today. One of the two Quaker meeting houses in Bristol was in Temple Street, just around the corner.

${ }^{3}$ See 'Hands across the Sea: Correspondence between Carletons in Ireland and America, 1752-1791', The Journal of the Friends' Historical Society 20 (1923), p.33-51, 116-25.

${ }^{4}$ The basic biographical facts concerning Lovell and his family are helpfully summarised in the Dictionary of Quaker Biography, an in-house compilation held at the Library of the Religious Society of Friends in Euston
} Road, London. I am grateful to David Blake, Head of Library and Archives, for help in sourcing this material. ${ }^{5}$ This myth is perpetuated in, for example, Richard Holmes, Coleridge: Early Visions (London: Hodder \& Stoughton, 1989), p.64, and Mark Storey, Robert Southey: A Life (Oxford: Oxford University Press, 1997), p.39. It seems to have had its origin in David Rivers's Literary Memoirs of Living Authors of Great Britain, 2 vols (London, 1798), vol. I.381-2. It is only fair to note that the error was pointed out by M. Ray Adams in Studies in the Literary Background of English Radicalism with Special Reference to the French Revolution (Westport: Greenwood Press, 1947), p.131. This neglected work is one of only two critical studies to give serious attention to Robert Lovell as a figure worthy of study in his own right.

${ }^{6}$ For background on Stephen Fricker, see Molly Lefebure, The Bondage of Love: A Life of Mrs. Samuel Taylor Coleridge (London: Victor Gollancz, 1986), p.23. Southey first mentions Lovellin a letter to Horace Walpole Bedford on 15 December 1793. He says that he has spent the evening with Lovell, who is to visit London the following week, and has entrusted to him a letter to Bedford's brother Grosvenor. He claims that he has 'sought [Lovell's] acquaintance' and that possessing philosophy, poetry, and a wife at the age of twenty-two is an uncommon state of affairs: 'Mr Lovel has the first \& will soon have the last. my younger years were past with his intended bride nor could I entertain a sincerer affection for a sister'. See The Collected Letters of Robert Southey: A Romantic Circles Electronic Edition (henceforth CLRS), ed. Lynda Pratt et al., http://www.rc.umd.edu/editions/southey_letters/Part_One/HTML/letterEEd.26.72.html [accessed 17 
September 2015]. I am grateful to Tim Fulford, one of the editors of this invaluable new edition, for his feedback on a draft of the present essay.

${ }^{7}$ For example, Lefebure describes how Lovell's father 'was against his son wedding an actress' but that Robert 'was used to displeasing his father and was going ahead with the marriage in spite of parental threats that he would be cut off with the proverbial shilling (threats which subsequently were to prove true)' (Bondage of Love, p.31). No source is cited for this colourful piece of reportage. In a similar vein, Basil Cottle, in Joseph Cottle and the Romantics (Bristol: Redcliffe Press, 2008), states that Lovell's 'marriage with the beautiful Mary Fricker, who had been on the stage, estranged him from his family' (p.27). Again, no source is cited.

${ }^{8}$ Ancient lease: Corporation of Bristol to Robert Lovell, BRO 1355/24 and 1355/35.

${ }^{9}$ Fired with Revolutionary enthusiasm, Coleridge sent 'Fraternity and civic Remembrances' to Lovell in his letter to Southey of 6 July; on arriving in Bristol, he wrote to Lovell to enquire of Southey's whereabouts, addressing him as 'Your fellow Citizen' See E. L. Griggs (ed.), Collected Letters of Samuel Taylor Coleridge, 6 vols (Oxford: Clarendon Press, 1956-71), vol. I.85, 96.

10 'Remembrancesof S.T.C. and R.S.', Harry Ransom Center, University of Texas at Austin, MS-0867.

${ }^{11}$ Cottle, Reminiscences, p.4.

${ }^{12}$ Monthly Magazine 48 (1819), p.204.

${ }^{13}$ 'Star Report of Bristol Guildhall Meetings of 17 and 20 November 1795', The Collected Works of Samuel Taylor Coleridge, vol. 1, ed. Lewis Patton and Peter Mann (London: Routledge \& Kegan Paul, 1971), p.361-2. Patton and Mann identify 'Mr Lovel' as Coleridge's Pantisocratic comrade and are most probably correct, although in the absence of further evidence it has to be possible that it was Robert Lovell's father who struggled to get heard.

${ }^{14}$ Cottle, Reminiscences, p.20.

${ }^{15}$ Lefebure, Bondage of Love, p.55. According to Lefebure, 'indolence' was the contemporary euphemism for opium addiction, although it was also used in the more familiar modern sense. Her suggestion that it was 'probably [...] Lovell alone who grasped the full implications of the situation' qualifies somewhat her earlier declaration regarding 'Lovell's discovery of S.T.C.'s opium indulgence' in Samuel Taylor Coleridge: A Bondage of Opium (London: Victor Gollancz, 1974), p.159; the evidence is thin either way. 
${ }^{16}$ M. Ray Abrams, Studies in the Literary Background of English Radicalism with Special Reference to the French Revolution (Westport: Greenwood Press, 1947), p.139. In early 1796, for example, Lovell was telling Southey that Coleridge was falsely claiming credit for parts of Southey's Joan of Arc. See Southey to Joseph Cottle, February-March 1796(?), CLRS, http://www.rc.umd.edu/editions/southey_letters/Part_One/HTML/letterEEd.26.148.html [accessed 17 September 2015].

${ }^{17}$ Cottle, Reminiscences, p.21.

${ }^{19}$ Sara Coleridge to Derwent Coleridge, 20-24 January 1836, Harry Ransom Center, University of Texas at Austen, MS-0866.

20 'Notes and Queries', The Journal of the Friends' Historical Society 25 (1928): 86.

${ }^{21}$ Mary Lovell to Sara Coleridge, 11 November 1840, Harry Ransom Center, University of Texas at Austin, MS0866.

${ }^{22}$ Michael Watts, The Dissenters: From the Reformation to the French Revolution (Oxford: Clarendon Press, 1978), p.286. Bristol had by far the greatest concentration of Quakers of any city or region in England and Wales; in London, by contrast, as Watts's tables show, they formed $1.4 \%$ of the population. The Quakers were, however, part of a much broader array of Nonconformist groups: James E. Bradley asserts that Bristol 'had the largest and most diverse Dissenting community in England'. See James E. Bradley, Religion, Revolution and English Radicalism (Cambridge: Cambridge University Press, 1990), p.199. Dissenters tended to congregate in particular parishes, and Lovell's address in his last years, 14 Old Market, puts him in the heartland of the Bristol Quaker community.

${ }^{23}$ Coleridge to Thomas Poole, 5 May 1796, Collected Letters, vol. I.208.

${ }^{25}$ Southey to Grosvenor Bedford, 14 December 1793, CLRS, http://www.rc.umd.edu/editions/southey_letters/Part_One/HTML/letterEEd.26.73.html [accessed 17 September 2015].

${ }^{26}$ Rayne Nickalls, 'Robert Lovell, The Quaker Pantisocrat', The Friends' Quarterly 10.1 (1956), p.137.

${ }^{27}$ Southey to Grosvenor Bedford, c.18 December 1793, CLRS, http://www.rc.umd.edu/editions/southey_letters/Part_One/HTML/letterEEd.26.74.html [accessed 17 September 2015]; Southey to Robert Lovell, 5-6 April 1794, CLRS, 
http://www.rc.umd.edu/editions/southey_letters/Part_One/HTML/letterEEd.26.85.html [accessed 17 September 2015].

${ }^{28}$ Coleridge to Robert Southey, 1 September 1794, Collected Letters, vol. I.99.

${ }^{30}$ Cottle, Reminiscences, p.4.

${ }^{31}$ Southey to Grosvenor Bedford, 14 December 1793, CLRS,

http://www.rc.umd.edu/editions/southey_letters/Part_One/HTML/letterEEd.26.73.html [accessed 17

September 2015]; Southey to Grosvenor Bedford, 20-21 July 1794, CLRS,

http://www.rc.umd.edu/editions/southey_letters/Part_One/HTML/letterEEd.26.96.html [accessed 17

September 2015]; Southey to Grosvenor Bedford, c.27 September 1794, CLRS,

http://www.rc.umd.edu/editions/southey_letters/Part_One/HTML/letterEEd.26.105.html [accessed 17 September 2015].

${ }^{32}$ Lovell followed up his visit with a letter, having been reluctant to 'intrude the subject' of emigration while Holcroft was in captivity. See P. P. Howe (ed.), The Complete Works of William Hazlitt, vol. 3 (London: J. M. Dent \& Sons, 1932), p.279.

${ }^{33}$ For Lovell's distaste for blood sports (an aversion he shared with Southey), see Southey to Horace Walpole Bedford, 24 January-18 February 1794, CLRS,

http://www.rc.umd.edu/editions/southey_letters/Part_One/HTML/letterEEd.26.80.html [accessed 17 September 2015]. For the anonymous character portrait, see The Observer, Part $1^{\text {st }}$ : Being a Transient Glance at about Forty Youths of Bristol (Bristol: J. Reed, n.d.), p.16. Georges Lamoine, in Notes on Bristol Literary

Circles, 1794-98 (Toulouse: Institut de Recherches Interdisciplinaire de I'Université de Toulouse-Mirail, 1973), judges on internal evidence that the pamphlet was printed 'some time after the beginning of July 1795 ' (p.9) and probably before Coleridge's and Southey's marriages in the autumn. Lovell's death in 1796 obviously closes the window within which publication might have taken place.

${ }^{34}$ In his Bristol: A Satire, Lovell refers to the brains of Bristol's materialistic inhabitants as acquiring a 'leaden mask'. The author of some spirited marginalia in a copy of the poem held by Bristol Reference Library is impelled to comment: 'It is but a mask, as Lovell found when some of them threw it off to kick him out of the theatre.' This story appears nowhere else in the documentary record pertaining to Lovell, so presumably the author was a contemporary who either witnessed the incident or heard of it soon after it occurred. 
${ }^{35}$ See in particular George Whalley, 'The Bristol Library Borrowings of Southey and Coleridge, 1793-8', The Library 4 (1949), p.114-32.

${ }^{36}$ Robert Lovell to Robert and Lydia Lovell, 21 May 1788, Library of the Religious Society of Friends, Crosfield MSS 99.

${ }^{37}$ Robert Lovell to Mary Lovell, 18 April 1796, Bristol Reference Library, MS B35257 SR 4 Pb Southey.

${ }^{38}$ Robert Lovell to Mary Lovell, 23 April 1796, Huntington Library, San Marino, California, HM 12297.

${ }^{39}$ Coleridge to Thomas Poole, 5 May 1796, Collected Letters, vol. I.208.

${ }^{40}$ Southey to Grosvenor Bedford, 27 May 1806, CLRS,

http://www.rc.umd.edu/editions/southey_letters/Part_Three/HTML/letterEEd.26.1188.html [accessed 17 September 2015].

${ }^{41}$ Southey to Charles Watkin Williams Wynn, 24 May 1796, CLRS,

http://www.rc.umd.edu/editions/southey_letters/Part_One/HTML/letterEEd.26.156.html [accessed 17 September 2015].

${ }^{42}$ Southey to Robert Lovell, Senior, 20 May 1796, CLRS, http://www.rc.umd.edu/editions/southey_letters/Part_One/HTML/letterEEd.26.155.html [accessed 29 February 2016].

${ }^{43}$ See Raymond D. Havens, 'Southey's Specimens of the Later English Poets', PMLA 60.4 (1945): 1072.

${ }^{44}$ Southey to Horace Walpole Bedford, 22[-24] December 1793, CLRS, http://www.rc.umd.edu/editions/southey_letters/Part_One/HTML/letterEEd.26.76.html [accessed 17 September 2015].

${ }^{45}$ Southey to Horace Walpole Bedford, 30[-31] December 1793, CLRS, http://www.rc.umd.edu/editions/southey_letters/Part_One/HTML/letterEEd.26.78.html [accessed 17 September 2015].

${ }^{46}$ William Bowles, whose Sonnets (1789) had been published by Cruttwell, recalled in later life how the latter had written to him about a visit from 'two young gentlemen' who 'spoke in high commendation of my volume, and $[. .$.$] expressed a desire to have some poems printed in the same type and form'. See the author's$ introduction to The Poetical Works of William Lisle Bowles, ed. Rev. George Gilfillan, 2 vols (Edinburgh: James Nicol, 1835), vol. I.3. 
${ }^{47}$ See Southey to Horace Walpole Bedford, 1 August 1794, CLRS, http://www.rc.umd.edu/editions/southey_letters/Part_One/HTML/letterEEd.26.97.html [accessed 22 February 2016].

${ }^{48}$ Southey to Robert Lovell, 5-6 April 1794, CLRS, http://www.rc.umd.edu/editions/southey_letters/Part_One/HTML/letterEEd.26.85.html [accessed 17 September 2015].

${ }^{49}$ Southey to Horace Walpole Bedford, 7 June 1794, CLRS, http://www.rc.umd.edu/editions/southey_letters/Part_One/HTML/letterEEd.26.93.html [accessed 17 September 2015]; Jeffrey N. Cox, 'Keats in the Cockney School', Romanticism 2.1 (1996), p.30.

${ }^{50}$ Southey to Thomas Southey, 19 October 1794, CLRS, http://www.rc.umd.edu/editions/southey_letters/Part_One/HTML/letterEEd.26.110.html [accessed 17 September 2015].

${ }^{51}$ Nickalls, 'Robert Lovell', p.138; Richard Holmes, Coleridge: Darker Reflections (London: HarperCollins, 1998), p.161. Nickalls cites Coleridge's later statement that 'I approve altogether \& embrace entirely the Religion of the Quakers, but exceedingly dislike the sect' (Coleridge to John Prior Estlin, 7 December 1802, Collected Letters, vol. II.893).

${ }^{52}$ Testimonies Concerning Ministers Deceased, vol. 3, Library of the Religious Society of Friends, YM/TCMD/3.

${ }^{53}$ Coleridge to Robert Southey, 11 December 1794, Collected Letters, vol. I.134.

${ }^{54}$ See Henry Nelson Coleridge (ed.), The Literary Remains of Samuel Taylor Coleridge, 4 vols (London: William Pickering, 1836-39), vol.I.3n for Southey's later account of the composition of this work.

${ }^{55}$ For a succinct account of the composition of Joan of Arc see Lynda Pratt (ed.), Robert Southey: Poetical Works, 1793-1810, 5 vols (London: Pickering \& Chatto, 2004), vol.I.xxxv-xl.

${ }^{56}$ David Fairer, Organising Poetry: The Coleridge Circle, 1790-1798 (Oxford: Oxford University Press, 2009), p.213, 211.

${ }^{57}$ Coleridge to Robert Southey, 13 November 1795, Collected Letters, vol. I.173.

58 Jeffrey N. Cox, 'Communal Romanticism', European Romantic Review 15.2 (2004), p.332.

${ }^{59}$ Richard Cronin, 'Joseph Cottle and West Country Romanticism', in Nicholas Roe (ed.), English Romantic Writers and the West Country (Basingstoke: Palgrave Macmillan, 2010), p.71. In the same volume, see also Paul 
Cheshire, 'William Gilbert and his Bristol Circle, 1786-98' (p.79-98). Cheshire describes Lovell as 'in the forefront of Pantisocracy' and as 'one herald of the British Romantic movement' (p.84).

${ }^{60}$ Southey to Horace Walpole Bedford, 30[-31] December 1793, CLRS, https://www.rc.umd.edu/editions/southey_letters/Part_One/HTML/letterEEd.26.78.html [accessed 17 September 2015]; Southey to Horace Walpole Bedford, 22[-24] December 1793, CLRS, https://www.rc.umd.edu/editions/southey_letters/Part_One/HTML/letterEEd.26.76.html [accessed 17 September 2015].

${ }^{61}$ The Annual Anthology, vol. I (Bristol and London: T. N. Longman and O. Rees, 1799), p.146. All parenthetical references to Lovell's poems are line references.

${ }^{62}$ Robert Lovell and Robert Southey, Poems (Bath: R. Cruttwell, 1795), p.73-5.

${ }^{63}$ Annual Anthology, vol. I.147.

${ }^{64}$ Romaine Thorn, Bristolia: A Poem (Bristol and London: Owen Rees and J. N. Longman, 1794), lines 53-6. Subsequent line references will be incorporated parenthetically in the text.

${ }^{65}$ Robert Lovell, Bristol: A Satire (London: Printed for the Author, 1794). Line references will be inserted parenthetically in the main text.

${ }^{66}$ Clarence Tracy (ed.), The Poetical Works of Richard Savage (Cambridge: Cambridge University Press, 1962), p.258, 260.

${ }^{67}$ Lovell does, however, coincide with Thorn in so far as he exempts Edward Colston from his disparagement of Bristolians' tightfistedness.

${ }^{68}$ George Eliot, Middlemarch, ed. David Carroll (Oxford: Clarendon Press, 1986), p.272, 205. 